\title{
HUKUM PERLINDUNGAN TERHADAP HAK-HAK PEKERJA RUMAH TANGGA
}

\author{
Sri Istiawati, SH,MH \\ Universitas Amir Hamzah \\ sriistiawati1962@gmail.com
}

\begin{abstract}
Abstrak
Bentuk Perlindungan Hukum terhadap Pekerja Rumah Tangga telah dijawab oleh pemerintah dengan adanya PERMENAKER RI Nomor 2 Tahim 2015 tentang Perlindungan Hukum bagi Pekerja Rumah Tangga (PRT), Pengguna (majikan) dan PRT wajib membuat Perjanjian Kerja tertulis atau lisan yang memuat hak dan kewajiban yang dapat dipahami oleh kedua belah pihak serta diketahui oleh Ketua Rukun Tetangga atau dengan sebutan lain di wilayah dimana PRT akan bekeija, dan dalam perjanjian kerja tersebut dijelaskan tentang hak dan kewajiban masing masing pihak yang bertujuan untuk memberikan kepastian dan perlindungan bagi kedua belah pihak. Peran Lembaga Penyalur Pekerja Rumah Tangga (LPPRT), adalah badan usaha yang wajib memiliki SIU-LPPRT, dan telah mendapat izin tertulis dari Gubemur atau pejabat yang ditunjuk untuk merekrut dan menyalurkan PRT, berperan untuk menyeleksi calon pengguna PRT, memastikan calon PRT dalam kondisi sehat dan dapat bekeija dengan baik, memonitor PRT yang telah disalurkan pada Pengguna, mengembalikan imbalan jasa sebagaimana dimaksud dalam Pasal 22 ayat (3) dalam hal PRT tidak bersedia mclanjutkan bekerja dalam waktu sekurang-kuranguya 6 (enam) bulan.
\end{abstract}

Keyword : Hukum Perlindungan, Hak-hak Pekerja Rumah Tangga.

\section{PENDAHULUAN}

Pekerja Rumah Tangga atau sering disebut pembantu rumah tangga adalah bagian dari masyarakat yang tidak berdaya di tengah modemisasi. Pekerja rumah tangga bekerja daiam lingkup rumah tangga yang sangat privat, dimana aturan main setiap rumah tangga berbeda-beda sehingga harus bisa mengikuti aturan main dalam keluarga majikan tersebut jika ingin tetap bertahan bekerja di rumah itu. Pembantu Pembantu Rumah Tangga merupakan bagian penting dalam keseharian

Jurnal Insitusi Politeknik Ganesha Medan 
masyarakay yang berumah tangga, bahkan terkadang menjadi orang kepercayaan dari majikan untuk mengurusi segaia keperluan yang ada dalam rumah tangga tersebut. Alasan klasik yang seringkali digunakan ketika seseorang memutuskan akan mempekerjakan pekerjaan rumah tangga adalah karena sibuknya pasangan suami-istri, rasa malas untuk melakukan pekerjaan rumah tangga, kurangnya keterampilan mengurus rumah tangga, khususnya memasak dan lain-lain, bahkan alasan kesepian. Dengan demikian, peran pembantu rumah tangga dalam kehidupan sehari-hari menjadi cukup penting. Perkembangan ruang lingkup pekerjaan yang dikerjakan di dalam rumah sesuai dengan kemajuan zaman. Temyata, ruang lingkupnya menjadi semakin luas dan kompleks. Pekerjaan seorang pekerja rumah tangga tidak hanya mengurus pekerjaan yang berhubungan dengan kerumah-tanggaan, seperti memasak, mencuci, merawat kebun, keahiian mengendarai kendaraan bermotor untuk keperluan antar jemput anak, merawat anak dan orangtua, sampai untuk mendampingi anak majikan ketika waktunya belajar. Ironisnya, secara sosial pekerja rumah tangga tidak dianggap sebagai sebuah profesi. Akronim PRI pun Icbih dipahami sebagai "Pembantu."' Sesuai perubahan era, sekarang ini dimulai dari kota-kota besar di Indonesia sudah lebih terbiasa menyebut para pekerja ini sebagai "Asisten R.umah Tangga" daripada sebutan sebagai "Pembantu," atau Pekerja Rumah Tangga. Namun sayangnya secara normatif, pekerja rumah tangga ini belum dianggap sebagai sebuah profesi karena aklifltas pekerja rumah tangga dianggap jauh dari aktifitas produksi. Sebagai imbasan atas pekerjaannya, pekerja rumah tangga menerima upah dari majikan. Besamya upah tergantung dari perjanjian dengan majikan yang seringkali didasarkan pada harga pasaran di suatu wilayah tertentu. Biasanya, pekerja rumah tangga menemukan majikan melalui penyaluran oleh teman, tetangga atau bahkan saudaranya sendiri, dan tidak memiliki kontrak kerja. Kesepakan dalam pekerjaan terjadi hanya secara lisan, disampaikan dengan saling memahami peran masing-masing, sehingga tidak ada kejelasan dalam hal jenis kerja, jam keija, dan upah yang diterimanya. Sejak awal hal ini menjadi pemicu munculnya berbagai permasalahan. Tidak jauh berbeda terhadap asisten/pekerja rumah tangga yang disalurkan melalui Lembaga Penyalur Pekerja Rumah Tangga (LPPRT), kontrak keija yang terjadi bukan antara Pekerja Rumah Tangga dengan Majikan, tetapi antara Penyalur dengan Majikan sehingga pekerja rumah tangga kembali menjadi obyek untuk dipeijual-belikan oleh Lembaga Penyalur Pekerja Rumah Tangga yang nakal atau tidak bertanggung-jawab

\section{KAJIAN PUSTAKA}

Pekerja Rumah Tangga adalah suatu posisi dalam kehidupan yang bersifat temporer. Pada awalnya, pekerja rumah tangga dapat dilihat sekilas dari proses perkembangan kebudayaan umum di Indonesia, seperti dalam kebudayaan Kraton Jawa, dimana daiam suatu keluarga yang terdiri dari ayah, ibu, dan anak-anak memiliki seorang pengasuh yang bekerja tidak hanya sekedar mengasuh dan menjaga anak selaina kedua orang tua bekerja, melainkan juga memiliki pekerjaan

Jurnal Insitusi Politeknik Ganesha Medan 
memasak, mencuci. dan lain sebagainya. Pada kebudayaan lainnya, posisi pengasuh juga memiliki arti penting dalam keluarga .

Perlindimgan Hukum dalam bahasa Inggris adalah "legalprotection" dalam bahasa Belanda, "rechtsbecherming." Kedua istilah tersebut juga mengandung konsep atau pengertian hukum yang berbeda imtuk member makna sesungguhnya dari "perlindungan hukum." Menurut Haijono, para pengkaji hukum belum secara komprehensif mengembangkan konsep "perlindungan hukum" dari perspektif keilmuan hukuin, tidak secara spesifik mendasarkan pada konsep-konsep dasar keilmuan hukum yang cukup dalam mengembangkan konsep perlindungan hukum. Bahkan dalam banyak bahan Pustaka, makna dan batasan-batasan mengenai perlindungan hukum sulit ditemukan. Hal ini mungkin didasari pemikiran bahwa orang telah dianggap tahu secara umum apa yang dimaksud dengan perlindungan hukum sehingga tidak diperiukan lagi sebuah konsep tentang apa yang dimaksud dengan Perlindungan Hukum. Konsekwensi dari tidak adanya konsep perlindungan hukum tersebut, akhimya menimbulkan keragaman dalam pemberian maknanya, padahal perlindungan hukum selalu menjadi tema pokok dalam setiap kajian hukum.

\section{DISCUSSION}

\section{A. Bentuk Perlindungan Hukum terhadap Pekerja Rumah Tangga (PRT)}

Pekerja rumah tangga merupakan posisi pekerjaan dalam miisyarakal yang tidak berdaya di tengah modemisasi. Mereka bekerja dalam lingkup mmah tangga yang sangat privat, dimana aturan main setiap rumali tangga berbeda-beda sehingga hams bisa mengikuti aturan main dalam keluarga majikan tersebut jika ingin tetap mempertahankan pekerjaannya, karena secara sosial pekerja rumah tangga tidak dianggap sebagai sebuah profesi. PRT pun lebih dipahami sebagai "Pembantu." Ironisnya, PRT merupakan bagian penting dalam keseharian masyarakat yang berumah tangga, bahkan terkadang menjadi orang kepercayaan dari majikan untuk mengurusi segaia keperluan yang ada dalam rumah tangga tersebut. Alasan klasik yang seringkali digunakan ketika seseorang memutuskan akan mempekerjakan pekerjaan romah tangga adalah karena sibuknya pasangan suami-istri, rasa malas untuk melakukan pekerjaan rumah tangga, kurangnya keterampilan mengurus rumah tangga, khususnya memasak dan lain-lain, bahkan alasan kesepian. Dengan demikian, peran pembantu rumah tangga dalam kehidupan sehari-hari menjadi cukup penting. Memang harus diakui bahwa, sampai saat ini keberadaan pekerja rumah tangga belum diakui sebagai tenaga kerja yang sama dengan tenaga kerja lainnya, seperti pekerja pabrik, buruh perusahaan, dan lain-lain. Bahkan harus diakui bahwa dewasa ini sebutan sebagai "pekerja" pun belum diterima masyarakat. Pada umumnya, masyarakat lebih menerima untuk menyeout Asisten Rumah Tangga sebagai "pembantu." Oleh karena itu, Asisten Rumah Tangga

Jurnal Insitusi Politeknik Ganesha Medan 
dimasukan dalam lingkup pekerjaan dalam sektor informal. Daiam UndangUndang Nomor 13 Tahun 2003 tentang Ketenagakerjaan mendefinisikan pekerja/buruh. Dalam Pasal 1 angka 3 rnenyebutkan bahwa, "Pekerja/buruh adalah setiap orang yang bekerja dengan menerima upah atau imbalan dalam bentuk lain." Berdasarkan pengertian tersebut nampak bahwa, seharusnya Pekerja Rumah Tangga termasuk daiam pekerja sektor formal yang dilindungi oleh ketentuan undang-undang .

\section{B. Peran Lembaga Penyalur Pekerja Rumah Tangga (LPPRT)}

Perkembangan ruang lingkup pekerjaan yang dikerjakan di dalam rumah sesuai dengan kemajuan zaman. Temyata, mang lingkupnya menjadi semakin luas dan kompleks. Pekerjaan seorang pekerja rumah tangga tidak hanya mengurus pekerjaan yang berhubungan dengan kerumah-tanggaan seperti memasak, mencuci, merawat kebun, keahiian mengendarai kendaraan bermotor untuk keperluan antar jemput anak, merawat anak dan orangtua, sampai untuk mendampingi anak majikan ketika waktunya belajar. Dalam melaksanakan pekerjaannya, seorang pekerja rumah tangga dituntut untuk menguasai banyak keterampilan untuk mendukung pekerjaannya, bahkan bisa mencakup perihal penanganan atas alat-alat elektronika, informatika, dan bertanggungjawab atas perangkat berteknologi mutakhir yang serba canggih. Perlindungan terhadap pekerja/burah dimaksudkan untuk menjamin terpenuhinya hak-hak dasar pekerja/buruh dan menjamin kesamaan kesempatan serta perlakuan tanpa diskriininasi atas dasar apapun untuk mewujudkan kesejahteraan pekerja/buruh dan keluarganya dengan tetap memperhatikan perkembangan kemajuan dunia usaha. Perlindungan hukum mempunyai makna sebagai perlindungan dengan menggunakan sarana hukum atau perlindungan yang diberikan oleh hukum, ditujukan kepada perlindungan terhadap kepentingan-kepentingan tertentu, yaitu dengan cara menjadikan kepentingan yang perlu dilindungi tersebut ke dalam sebuah hak hukum. Dalam ilmu hukum, "Hak" disebut juga hukum subyektif, Hukum subyektif merupakan segi aktif dari hubungan hukum yang diberikan oleh hukum obyektif (norma-norma, kaidah, recht).

Perlindungan hukum selalu terkait dengan peran dan fungsi hokum sebagai pengatur dan pelindung kepentingan masyarakat, Bronislaw Malinowski dalam bukunya berjudul. Crime and Custom in Savage, mengatakan bahwa, "hukum tidak hanya berperan di dalam kcadaan-keadaan yang penuh kekerasan dan pertentangan, akan tetapi bahwa hukum juga berperan pada aktivitas sehari-hari.

\section{KESIMPULAN}

\section{Kesimpulan}

1. Bentuk Perlindungan Hukum terhadap $\mathrm{I}^{\wedge} \mathrm{ckcrja}$ Rumah Tangga telah dijawab oleh pemerintah dengan adanya PERMIiNAKER Rl Nomor 2 Tahun 2015

Jurnal Insitusi Politeknik Ganesha Medan 
tentang Perlindungan Hukum $b^{\wedge}$ gi Pekerja Rumah Tangga (PRT), Pengguna (majikan) dan PRT wajib membuat Perjanjian Kerja tertulis atau lisan yang memuat hak dan kewajiban yang dapat dipahami oleh kedua belah pihak serta diketahui oleh Ketua Rukun Tetangga atau dengan sebutan lain di wilayah dimana PRT akan bekerja, dan dalam perjanjian kerja tersebut dijelaskan tentang hak dan kewajiban masing masing pihak yang bertujuan untuk memberikan kepastian dan perlindungan bagi kedua belah pihak.

2. Peran Lembaga Penyalur Pekerja Rumah Tangga (LPPRT), adalah badan usaha yang wajib memiliki SIU-LPPRl, dan telah mendapat izin tertulis dari Gubernur atau pejabat yang ditunjuk untuk merekrut dan menyalurkan PRT, berperan untuk menyeleksi calon pengguna PR T, memastikan calon PRT dalam kondisi sehat dan dapat bekerja dengan baik, memonitor PRT yang telah disalurkan pada Pengguna, mengembalikan imbalan jasa sebagaimana dimaksud dalam Pasal 22 ayat (3) dalam hal PRT tidak bersedia melanjutkan bekerja daiam waktu sekurang kurangnya 6 (enam) bulan.

\section{Saran}

1. Perlindungan hukum terhadap PRT yang dimaksudkan untuk menjamin terpenuhinya hak-hak dasar mereka dan menjamin kesamaan kesempatan serta perlakuan tanpa diskriminasi atas dasar apapun, maka perlu menggunakan sarana hukum atau perlindungan yang diberikan oleh hukum.

2. PRT dan Pengguna (majikan) wajib membuat Perjanjian Kerja tertulis atau lisan yang memuat hak dan kewajiban yang dapat dipahami oleh kedua belah pihak serta diketahui oleh Ketua Rukun Tetangga atau dengan sebutan lain di wilayah domisili majikan sebagai tempat PRT bekerja.

\section{REFERENCES}

\section{Buku}

Abdulkadir Muhammad, Hukum dan Penelitian, Citra Aditya Bajti, Bandung, 2004

Adrian Sutedi, Hukum Perburuhan, Sinar Grafika, Jakarta, 2009

Asri Wijayanti, Hukum Ketenagakerjaan Pasca Reformasi, Sinar Grafika, Jakarta, 2009

Burhan Ashsofa, Metode Penelitian Hukum, Rineka Cipta. Jakarta. 2001

Djoko Triyanto, Hubungan Kerja di Perusahaan Jasa Konstruksi, Mandar Maju, Bandung, 2004 
Harjono, Konstitusi Sebagai Rumah Bangsa, I*enerbit Sekretariat Jenderal dan Kepaniteraan Mahkamah Konstitusi, 2008

Imam Soepomo, Rachmat, Pengantar Hukum Perburuhan, Djambatan, Jakarta, 2003

Nyoman Serikat Putra Jaya, Beberapa Pemikiran ke Arah Pengembangan Hukum Pidana, PT. Citra Aditya Bakti. Bandung, 2008

PNH Simanjuntak, Pokok-pokok Hukum Perdata Indonesia, Djambatan, Jakarta, 2005

Rachmad Syafa'at, Gerakan Buruh dan Pemenuhan Hak Dasarnya, Strategi Buruh dalam Melakukan Advokasi. In- TRANS Publising, Malang, 2008

R Gunawan Oetomo, Pengantar Hukum Perburuhan dan Hukum Perburuhan di Indonesia, Grhadika Binangkit Press, Jakarta, 2004

Sehat Damanik, Outsourcing Perjanjian Kerja menurut UU No. 13 Tahun 2003 tentang Ketenagakerjaan. DSS Publishing, 2006

\section{Internet}

http://www.gaiimu.com.

http://id.wikipedia.org/.../;;eXe/7a_n;/wi/i_rurtgg(:i diakses 1 Maret 2016

\section{Undang-undang}

Undang-Undang RI No. 13 Tahun 2003, Pasal 50

PERMENAKER RI No.2 1 ahun 2015, Pasal (1)

Undang-Undang No. 13 Tahun 2003 tentang Ketenagakerjaan (Pasal 1(3)) 